\title{
THE FINANCIAL AND NON-FINANCIAL CONTRIBUTION OF BANKING SECTOR ON FOREIGN TRADE OF COUNTRIES: COINTEGRATION ANALYSIS AND TEB BUSINESS CASE
}

\author{
DOI: 10.17261/Pressacademia.2019.1168 \\ JBEF- V.8-ISS.4-2019(7)-p.247-258
}

\section{Ebru Gul Yilmaz}

Istanbul Gelişim University, Department of International Trade Department, Istanbul, Turkey. egyilmaz@gelisim.edu.tr, ORCID: 0000-0002-3610-4982

To cite this document

Yilmaz, E.G. (2019), The financial and non-financial contribution of Turkish banking sector on foreign trade of countries: cointegration analysis and TEB business case. Journal of Business, Economics and Finance (JBEF), V.8(4), p.247-258

Permemant link to this document: $\underline{\text { http://doi.org/10.17261/Pressacademia.2019.1168 }}$

Copyright: Published by PressAcademia and limited licenced re-use rights only.

\begin{abstract}
Purpose- Turkey, along with the economic decisions of January 24 in 1980, has begun to apply liberal trade policies. After 1980s foreign trade volumes and capital movements has begun to experience severe accelerations. The banking system has become the major mediator of this period. The banks have very important roles, such as brokering foreign trade transactions, following export commitments, allocating loans to exporters, opening letters of credit, informing companies of the legislative point of view as well as providing consultancy services; in other words, they continue to fulfill the functions that do not generate income by non-financial means. The aim of this research is to analyze the contribution of the banking system on foreign trade of the countries with the help of taking Türk Ekonomi Bankası (TEB) as a business case and search the cointegration between Eximbank loans (exports supporting product) and letter of credit and bank acceptance (imports supporting product) and volume of foreign trade for Turkey

Methodology- ARDL, FMOLS and DOLS methods for the period 2001-2018 are used for the empirical analysis, before cointegration analysis Zivot Adrews, ADF (Augmented Dickey Fuller), PP (Phillip Perron), KPSS are used as unit root tests, CUSUM and CUSUM square tests are used for determining the stability of the coefficients and taking Türk Ekonomi Bankası a business case for analyzing the non-financial contribution of the sector on foreign trade

Findings- It was concluded that a $1 \%$ increase in the credit volume in the long term caused an increase in the foreign trade volume between $0.88 \%$ and $95 \%$.

Conclusion- It was concluded that a $1 \%$ increase in the credit volume in the long term caused an increase in the foreign trade volume between $0.88 \%$ and $95 \%$. Especially result gained on empirical part of the paper shows us once again how important it is for banks, one of the most important actors in the financial systems of the countries, to continue their activities effectively.
\end{abstract}

Keywords: International trade, foreign trade, banking sector, cointegration, ARDL, FMOLS, DOLS

JEL Codes: E02, F10, 039

\section{INTRODUCTION}

The concept of International trade took place for the first time in the book of Adam Smith, Wealth of Nations, published in 1776. Adam Smith, one of the representatives of classical economics, argues with the Theory of Absolute Advantages in his book that the foreign trade should be free, and that a country to import a product that can be produced by using less production factor in another country and export a product that can be produced by using less production factors in itself will support the labor division and specialization and thus increase the welfare level of the World along with increasing efficiency. (Karluk, 2013, s: 28). The development and acceleration of foreign trade coincides with the aftermath of World War II. In 1820, the share of world exports in the world gross national product was $1 \%$, while it was $5.5 \%$ in 1950 , this ratio increased to $35 \%$ as of 2017 as a result of the developments after world war II. (World Bank, 2018) Today even though intense trade wars are being experienced, it is 
difficult to even imagine a world without international trade. On the other hand, as the main actors of the financial system, banks offer short-term export credit facilities for the growth and development of the real sector and export credit facilities to support long-term foreign trade for investment financing. It is natural that banks obtain interest and commission income from these activities and the said product and service group have the same structure and characteristics in almost all deposit banks. On the one hand, banks are similar to other commercial enterprises in terms of being profit-making organizations yet on the other hand they differ with their undeniable and large-scale effects on the real sector.

In this paper the effects of banking sector on foreign trade will be investigated in the separation od two parts; financial affects and non-financial effects. On the non-financial effect section Türk Ekonomi Bankası activities on foreign trade will be analyzed. Türk Ekonomi Bankası has been chosen out of other commercial banks because of its unique partnership with TiM- Turkish Exporters Assembly.

What was aimed at the financial aspect; empirical part of the study was to search for the presence of cointegration between the cash and non-cash loans disbursed by commercial banks and Eximbank in order to support foreign trade in Turkey and total volume of foreign trade. In the study, in addition to the cash export loans extended through the banking sector, non-cash ones; letters of credit and acceptance loans, which allow the sector to guarantee the import transactions, are considered as independent variables as total loans. As of the independent variable total foreign trade volume was based on.

\section{LITERATURE REVIEW}

In the literature, rather than researches on the effects of the banking sector on foreign trade, heavily on the effects of foreign capital inflows on the banking sector were observed. In the research of Acar, performed by survey method in 2009 it was emphasized that, the fact that after the 2008 America Mortgage crisis the financing taps were narrowed for foreign trade and operation costs of foreign trade were raised, caused a contraction in foreign trade for them mentioned period in Turkey. According to this study, pre-export financing creation was considered as an obstacle in terms of export growth for $32,5 \%$ of the survey participants. In the study by Ozturk et al in 2007 aimed to measure the contribution of Eximbank to Turkish export by calculating the share in exports of the total loans granted by Eximbank over the years, it was concluded that Eximbank did not provide a significant contribution to the Country's export. In 2016, Alpdündar repeated the same study with the same method and found that the contribution rate determined at similar rates was high. Küçükaksoy et al in their study carried out in 2015, have targeted to test genuineness of export-based growth hypothesis within the particular scope of Turkey. In this study, it has been concluded by using FMOLS, CCR, DOLS methods that $1 \%$ growth in exports caused an increase of $1.3 \%$ and $1.55 \%$ on gross domestic product.

No study has been found in which the contributions of the banking sector to the foreign trade of the country have been analyzed as case study within a scope of a particular bank. For this reason, the literature review was directed to the studies carried out to determine the success factors in foreign trade and whether the success factors identified were presented to the customers by the Turkish Economy Bank, which was analyzed as a case study, was planned to be included in the study.

Critical elements of being successful in international trade have attracted the attention of various researchers from different countries and analyzes have been attempted to be conducted mostly by using questionnaire and interview methods. Madsen (1989) in the study conducted within the particular scope of Denmark, with 82 exporters operating in the SME segment among the 9000 producer exporters in the country, using the survey method prepared in scale of 7-point Likert and Stapel, aimed at measuring the effects of the variables determined 'Company characteristics', Export Marketing Policy' and 'Market Characteristic' on the export success of firms. As a result of the study: • making full use of the existing export markets rather than opening to new markets $\bullet$ establishing good personal contacts with contact persons in the exporting countries and getting ideas on of how he/she works • providing a strong and quality product $\bullet$ approaching cautiously to low price strategy $\bullet$ internalizing the export strategy • giving the decision-making authority to people who know and understand the market • selecting nearby markets instead of remote, exotic markets • selecting markets with high growth and low local competitiveness are determined to be critical success factors for success in exports.

Yücel stated in a study conducted in 2018 that export marketing strategies and firm performance are closely related; that it is essential to find new markets for companies to take place permanently in the international arena, to modify their products in accordance with the market needs and / or to design new products, to perform market segmentation and to make market selection after performing target market analyzes. 
Dhliwayo (2017) in his study; identified three titles as the main success factor in cross-border trade which are, the ability to identify potential customers, the ability to find the necessary resources and credit support, and to manage the process, import and export legislation, tariffs and customs practices.

Goldberg and Pallini (2008), on the other hand, considered education, use of technology and business connections as the most important success factors.

\section{DATA AND METHODOLOGY}

Eximbank loans intended to support exports and non-cash letters of credit and acceptance loans used to support imports and which is the financial institutions are the guarantor of the importer assigned as independent variables. All of these data were obtained from the Statistical Reports Section of the Banks Association for the period 2001-2018.

Table 1: Dependent and Independent Variables

\begin{tabular}{|c|c|c|c|c|c|c|c|}
\hline (Milyon USD) & \multicolumn{3}{|c|}{ Independent Variable } & \multicolumn{3}{c|}{ Dependent Variable } \\
\hline Period & $\begin{array}{c}\text { Eximbank } \\
\text { Loans }\end{array}$ & $\begin{array}{c}\text { Letter of } \\
\text { Credit }\end{array}$ & $\begin{array}{c}\text { Acceptance } \\
\text { Credits }\end{array}$ & $\begin{array}{c}\text { Total Credit } \\
\text { Trade Volume }\end{array}$ & Imports & Exports & \multicolumn{1}{|c|}{ Vorign } \\
\hline 2001 & 4.434 & 6.499 & 1.710 & 12.643 & 41.399 & 31.334 & 72.733 \\
\hline 2002 & 2.789 & 5.663 & 1.310 & 9.763 & 51.554 & 36.059 & 87.613 \\
\hline 2003 & 2.480 & 6.766 & 1.741 & 10.987 & 69.340 & 47.253 & 116.593 \\
\hline 2004 & 2.442 & 8.023 & 2.122 & 12.587 & 97.540 & 63.167 & 160.707 \\
\hline 2005 & 2.225 & 9.073 & 1.894 & 13.191 & 116.774 & 73.476 & 190.251 \\
\hline 2006 & 2.384 & 10.667 & 1.777 & 14.828 & 139.576 & 85.535 & 225.111 \\
\hline 2007 & 2.486 & 12.811 & 1.930 & 17.226 & 170.063 & 107.272 & 277.334 \\
\hline 2008 & 3.156 & 16.694 & 2.468 & 22.318 & 201.964 & 132.027 & 333.991 \\
\hline 2009 & 2.529 & 13.287 & 1.906 & 17.722 & 140.928 & 102.143 & 243.071 \\
\hline 2010 & 2.775 & 18.484 & 2.314 & 23.572 & 185.544 & 113.883 & 299.428 \\
\hline 2011 & 4.827 & 22.480 & 3.837 & 31.144 & 240.842 & 134.907 & 375.749 \\
\hline 2012 & 7.450 & 21.016 & 4.705 & 33.170 & 236.545 & 152.462 & 389.007 \\
\hline 2013 & 12.103 & 26.437 & 6.618 & 45.158 & 251.661 & 151.803 & 403.464 \\
\hline 2014 & 14.584 & 24.743 & 6.677 & 46.005 & 242.177 & 157.610 & 399.787 \\
\hline 2015 & 15.873 & 23.591 & 5.520 & 44.984 & 207.234 & 143.839 & 351.073 \\
\hline 2016 & 20.413 & 23.951 & 6.350 & 50.714 & 198.618 & 142.530 & 341.148 \\
\hline 2017 & 22.025 & 24.997 & 6.825 & 53.846 & 233.800 & 156.993 & 390.793 \\
\hline 2018 & 26.810 & 19.161 & 7.170 & 53.142 & 223.039 & 168.023 & 391.062 \\
\hline
\end{tabular}

Source: The Statistical Reports Section of the Banks Association

\subsection{Theoretical Model}

The analysis was aimed at the existence of the cointegration relationship of the foreign trade volume with the cash and noncash loans for import and export, 'exchange rate' variable, whose impact on foreign trade volume has come up with many studies, is also included in the model. Model:

InTotalForeignTrade $=\alpha+\beta$ lnCred $.+\delta \ln E x c h a n g e r a t e+v t$

*InForeign Trade: The volume of foreign trade consisting of the total of import and export logarithms.

*InCred: Logarithms of total of Eximbank cash loans, letters of credit and acceptance credits

*InExchangerate: The logarithm of the CBRT exchange buying rate average of the year. 
It is expected that the increase in Eximbank loans used to support exports or the letters of credit and acceptance loans extended to support imports will lead to an increase in foreign trade volumes in the same year.

\subsection{Methodology}

ARDL (Autoregressive Distributed Lag Model) cointegration approach was used to determine the existence of long-term relation with the foreign trade volume of the support provided by the banking sector by providing cash financing and non-cash guarantees. In addition to ARDL, FMOLS (Fully Modified Least Squares) and DOLS (Dynamic Least Squares) methods have been used to examine the long-term presence of the relationship between variables. ARDL method is preferred because the data set covers the years 2001-2018 due to the fact that non-cash loans data are available since 2001. Having to work with 18 annual data led to the selection of the ARDL model which is suitable for obtaining the most effective result with less data in cointegration analysis. The rationale for using FMOLS and DOLS methods is that they provide reliable results in small data sets sample amount of which is small such as ARDL. (Erdoğan et al; 2018:47) However, even if there is no significant and real relationship between the variables in the model $y t=\alpha+\beta x_{1}+u t$, in cases that they have a common trend, as a result of the model estimate high $\mathrm{R}^{2}$; the counterfeit regression result may be faced (Favero, 1999:46). In order to avoid such problem, ADFAugmented Dickey Fuller, PP-Philip Perron, KPSS-Kwiatkowski-Philipps-Schmidt-Shin stationarity tests were applied for dependent and independent variables. In addition, although it is possible to ignore structural changes reduce the power of stationary tests. the Zivot Andrews test, which considers structural breaks, is also included in the study,

Another point that makes ARDL method necessary is that variables have become static at different levels. None of the cointegration methods proposed by Engle and Granger (1987), Johansen (1988), Johansen and Juselius (1999) provide the opportunity to analyze the sets of data that become inert at different levels. The ARDL (Autoregressive Distributed Lag) approach developped by Pesaran et al. (1996) Pesaran and Shin (1995) Pesaran et al. (2001), has overcome the aforementioned problem and allows cointegration analysis with data sets with different levels of inertia (Altıntaş, 2008: 30). The ARDL model is used to model the relationship between variables in a single equation time series setup (Kripfganz ve Schneider, 2016: 2). Distributed autoregressive models - ARDL are models with lagged series of dependent variables as well as independent variables (Johnston ve Dinardo, 1997:246). The ARDL boundary test is performed in three steps. The first stage is the determination of the existence of the long-term relationship between the variables in the model. At this stage, $\mathrm{F}$ statistics are applied to the first level delays of the variables. The results of the F statistic are compared with the table in which the lower and upper critical values in the 2001 analysis of Pesaran et al. If the result is greater than the upper and lower values in the mentioned table, it means that the existence of a long-term relationship between the variables. The second stage is the estimation stage of the cointegration relationship after the determination of the long-term relationship. As for the final step, its is the realization of the short-term prediction including the delay of the error term in the cointegration model. (Çetin et al., 2014: 255). DOLS-Dynamic Least Squares Method and FMOLS-Fully Modified Least Squares Method and CCR-Canotic Cointegration Recession Method are two other methods used to estimate long-term coefficients after the determination of the existence of long-term relationship. All three methods are advised by Philip and Hansen (1990); In order to avoid the problem of causing hypothesis tests to be invalid of the estimation of the model by ordinary least-squares method, in case the variables are static at first degree and there is a cointegrated vector between the variables. (Küçükaksoy et al, 2015: 706).

\section{FINDINGS AND DISCUSSIONS}

\subsection{ADF-PP-KPSS-ZA Unit Root Test Results}

In all tests carried out to search for the presence of unit root, it was concluded that the data series were not static at the level, structural breaks were involved, and they were static at first degree.

Table 2: ADF-KPSS-PP Unit Root Test Results

\begin{tabular}{l|l|l|l|l|l|l|l|l|l} 
& \multicolumn{3}{|c|}{ ADF } & \multicolumn{3}{c}{ KPSS } & \multicolumn{3}{c}{ PP } \\
\hline Variables & $\begin{array}{l}\text { Level Fixed } \\
\text { and Trend }\end{array}$ & $\begin{array}{l}\text { First } \\
\text { Difference } \\
\text { Fixed and } \\
\text { Trend }\end{array}$ & Decision & $\begin{array}{l}\text { Level Fixed } \\
\text { and Trend }\end{array}$ & $\begin{array}{l}\text { First } \\
\text { Difference } \\
\text { Fixed and } \\
\text { Trend }\end{array}$ & Decision & $\begin{array}{l}\text { Level } \\
\text { Fixed and } \\
\text { Trend }\end{array}$ & $\begin{array}{l}\text { First } \\
\text { Difference } \\
\text { Fixed and } \\
\text { Trend }\end{array}$ & Decision \\
\hline
\end{tabular}




\begin{tabular}{l|l|l|l|l|l|l|l|l|l}
\hline LogForeign & $-1,692$ & $-3,954$ & $(\mathrm{I})$ & 0,1776 & 0,500 & $(0)$ & $-2,490$ & $-6,629$ & $(\mathrm{I})$ \\
Trade. & $(-3,710)^{*}$ & $-(3,759)^{*}$ & & $(0,1460)$ & $(0,1460)$ & & $(-3,710)$ & $(-3,733)$ & \\
\hline LogCredit & $-3,880$ & $-5,425$ & $(\mathrm{I})$ & 0,1050 & 0,1785 & $(1)$ & $-3,880^{*}$ & $-6,490$ & $(0)$ \\
& $(-3,710)^{*}$ & $(-3,733)^{*}$ & & $(0,1460)$ & $(0,1460)$ & & $(-3,710)$ & $-3,733$ & \\
\hline Logexchange & 1,087 & $-4,748$ & $(\mathrm{I})$ & 0,1831 & 0,1480 & $(0)$ & 2,316 & $-9,358^{*}$ & $(1)$ \\
rate & $(-3,759)^{*}$ & $(-3,759)^{*}$ & & $(0,1460)$ & $(0,1460)$ & & $(-3,710)$ & $(-3,733)$ &
\end{tabular}

* The table is organized according to $5 \%$ significance level and Schwarz criteria.

Table 3: Zivot-Andrews Unit Root Test Results

\begin{tabular}{l|c|c} 
& Zivot Andrews & \\
\hline Variables & Model C & Breaking year \\
\hline LogForeign Trade & $-2,998$ & 2007 \\
& $(-5,08)^{*}$ & 2013 \\
\hline LogCredit & $-5,69$ & 2004 \\
\hline Logexchange rate & $(-5,08)^{*}$ &
\end{tabular}

* The table is organized according to $5 \%$ significance level and Schwarz criteria.

\subsection{ARDL Results}

ARDL was analyzed separately for the presence of both short- and long-term relationship. According to ARDL Boundary test results F statistics; 5.95 has a value higher than the lower and upper limit values at all levels of significance (Table 3). Therefore, it can be said that there is a long-term cointegration relationship between the variables. After determining the existence of cointegration relationship, short and long term relation analysis was started.

\section{Table 4: ARDL Boundary Test Results}

\begin{tabular}{|c|c|c|c|c|}
\hline Model & Optimal Delay & F Statistics* & \multicolumn{2}{|c|}{ Boundary Test Critical Values } \\
\hline & & & Lower & Upper \\
\hline f(logTrade; logCredit, logexchange rate) & $1,0,3$ & 5,947681 & 3,1 & 3,87 \\
\hline
\end{tabular}

* Analysis is tabulated according to $5 \%$ significance level.

CUSUM in Graph 4 and CUSUMQ tests in Graph 5 (Brown, Durbin and Evans, 1975) are used to determine the stability of the coefficients of the long-term model. CUSUM is used to determine whether the error terms are within the $95 \%$ confidence interval and CUSUMQ used to determine if the squares of the cumulative error terms are within the desired limits. (Çetin et al., 2014: 257) According to both tests, there is no break in the model.
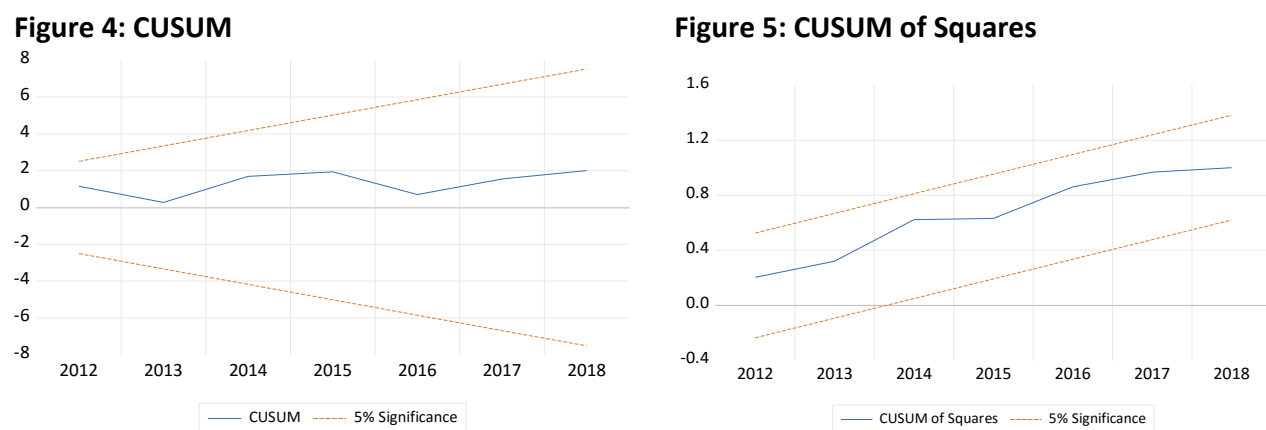

When short-term error correction model is taken into consideration, $37 \%$ of shocks arising from total foreign trade volume, exchange rate and total credit volume normalize in a period and the cycle comes to long-term balance again. (Table 4) 
Table 5: Short Term Relationship Analysis

\begin{tabular}{lrrrr} 
Variables & Coefficient & Standard Error & t-statistics & Probability Values \\
\hline \hline D(LOGTRADE(-1)) & -0.617670 & 0.217816 & -2.835743 & 0.0252 \\
D(LOGCREDIT) & 1.078902 & 0.083656 & 12.89687 & 0.0000 \\
D(LOGCREDIT(-1)) & 1.274665 & 0.312882 & 4.073950 & 0.0047 \\
ECM (-1) & -0.369571 & 0.067540 & -5.471906 & 0.0009
\end{tabular}

* Analysis is tabulated according to $5 \%$ significance level via ARDL Panel Method

\subsection{Long Term Relationship Analysis: FMOLS and DOLS Results}

In the model, the coefficient of exchange rate $\tau$ and the coefficient of credit volume $\beta$ represent the flexibility of the foreign trade volume to these variables. With this viewpoint, when FMOLS and DOLS results are evaluated, it is seen that credit volume has positive effect on total foreign trade volume according to both test outputs.

An $1 \%$ increase in credit volume leads to $0,88 \%$ increase in foreign trade volume according to DOLS results (Table 6$)$ and $0,95 \%$ increase according to FMOLS results (Table 7).

Table 6: DOLS Results

\begin{tabular}{|l|c|c|c|c|c}
\multicolumn{1}{l|}{ Variables } & Coefficient & Standard Error & t-statistics & Probability Values & \multicolumn{2}{c}{$\mathbf{R}^{\mathbf{2}}$} \\
\hline \hline LOGCREDIT & 0.877280 & 0.223727 & 3.921213 & 0.0078 & \multirow{2}{*}{0,976} \\
\cline { 1 - 4 } LOGEXCHANGE RATE & -0.480463 & 0.237061 & -2.026750 & 0.0891 & \\
\hline C & 3.886972 & 2.059545 & 1.887297 & 0.1081 & \\
\hline
\end{tabular}

Table 7: FMOLS Results

\begin{tabular}{|c|c|c|c|c|c|}
\hline Variables & Coefficient & Standard Error & t-statistics & Probability Values & $\mathbf{R}^{2}$ \\
\hline LOGCREDIT & 0.954731 & 0.137664 & 6.935250 & 0.0000 & \multirow{3}{*}{0,88} \\
\hline LOGEXCHANGERATE & -0.446175 & 0.212052 & -2.104087 & 0.0539 & \\
\hline $\mathrm{C}$ & 3.098141 & 1.290803 & 2.400166 & 0.0309 & \\
\hline
\end{tabular}

\section{BUSINESS CASE EVALUATION OF TURKISH ECONOMY BANK}

After the economic liberalization in the banking sector after 1980, especially with decision no: 32 on the Law on the Protection of the Turkish Currency (TPKK) issued in 1989, the banking sector was installed important missions in foreign trade intermediation. With this decision, banks have been given the authority to hold foreign exchange positions, open foreign currency deposit accounts, act as intermediaries in import-export transactions and undertake the obligation to follow the export commitment.

Türk Ekonomi Bankası was established in 1927 and in 2005, established a strategic partnership with the French Bank Paribas by selling 50\% of the Bank's stocks open to public and thus joined BNP Paribas' network of 100 commercial centers in 60 countries (trade center). In Turkey, with trade centers established in Istanbul, Izmir and Adana Bank is providing consultancy services to companies in foreign trade and provide support for banking.

The services other than the products and services offered by the Bank through branches in foreign trade are; TEB Foreign TradeForeign trade portal, TEB Enterprise House, TEB-TIM cooperation, TEB SME TV, Trade Center and TEB Legislation Unit. The services mentioned will be evaluated in detail in this study. 
In particular, by analysing this case study, students of International Trade, Banking and Insurance, Economics Departments, academicians, bankers and company executives engaged in foreign trade activities will be able to;

$>$ Compare Turkey's foreign trade structure the before and after 1980

$>$ Comprehend the structural changes in Turkish banking system after 1980.

$>$ Analyze the non-financial support of the banking system other than main financial activities such as allocating loans for the foreign trade of the country in a multi-faceted way within the particular scope of Turkish Economy Bank

\subsection{TEB-Turkey Exporters Assembly Cooperation Protocol}

Turkey Export Assembly (TIM) within the scope of Turkey Export Strategy and Action Plan adopted for the year 2023 realized a protocol. for cooperation with the Turkish Economy Bank

The advantages of the protocol to TIM member companies are related to foreign trade transactions are as follows;

- Special definition for import-export, arbitrage, spot foreign exchange transactions in order to benefit from exchange rate advantage in intern et branch usage

- $\quad$ Special interest rate

- Application of maximum commission of $1 \%$ for letters of guarantee issued as collateral for short-term export credits

- Providing free foreign trade seminars, consultancy and training opportunities

- Discounted tariff document preparation service

- $\quad$ Discount on insurance products

- Special pricing from TEB Factoring in export factoring transactions and,

- Free of charge cash flow for six months. (Annex: 1)

The most remarkable points in the cooperation protocol with TiM are that the Bank's training, consultancy and seminar services are provided free of charge for an unlimited period of time, Foreign Trade portal, which provides important contributions to companies for opening up new foreign markets is provided free of charge for one year. On the other hand, providing the opportunity to optimize the matters such as additional transportation costs, market research costs, intelligence costs which may be considered as disadvantages of foreign trade compared to local trade through provided privilages and supports is considered as an issue of importance.

\subsection{Trade Center Structure}

Standard customer segmentation of banks-segmentation structure for corporate customers is predominantly carried out by taking into account the annual net sales figures of customers. Most banks' corporate customer segmentation is made as; corporate, commercial, SME, business, micro, product diversity, organizational structuring and localization are differentiated in accordance with the said segmentation. Turkish Economy Bank went beyond the standard segmentation and became involved in the structure of the trade center of its shareholder, BNP Baribas.

During the meeting with TEB top management, it was stated that it would be possible that its trade centers would be able to offer global, not local, solutions through the use of BNP Paribas' 100 trade center networks in 80 countries; It is stated that endto-end solutions can be offered in the relationship established by domestic companies with foreign trade partners, and consultancy can be given to the market research process of domestic companies with a team specialized in foreign trade.

\subsection{TIM TEB Enterprise House}

TEB Enterprise House was established to provide support to those who want to start a business in order to produce and sell value-added products in three main subjects: 'Business Management Consultancy', 'Entrepreneurship Trainings' and 'Incubation Center. Currently TEB Enterprise House is providing logistic support to entrepreneurs such as meeting room, wireless internet connection, printer, scanner, fax as well as training support in nine points as -West Ataşehir, ITU Teknokent Maslak, and as eoffice, Yesilkoy, Bakirkoy, Gayrettepe, Maslak, Istiklal Street, Kadikoy and Atasehir, office, As the main purpose supporting foreign trade and as the particular purpose is to provide the opportunity to benefit from the TiM-TEB Growth Circuit San Francisco-America office, which provides the opportunity to meet with the global investors and introduce the developed technologies abroad to the two customers identified as having the potential to open to the foreign market. Aslı Semerci, who 
met TIM-TE Intervention House after her participation in TÜBіTAK's Individual Young Intervention Program, is one of the examples that stepped into entrepreneurship to work on a test that will highlight the current diagnostic process of Alzheimer's disease. Under the umbrella of the company Semerci Genecare Tekonoloji, TiM-TEB Enterprise House is still in preparation for production of a few products which are currently consumed in our country but not produced and therefore have to be imported.

\subsection{Foreign Trade Portal (www.tebledisticaret.com)}

The portal which was launched in 2016 is the first and unique in the sector. In case Turkish companies decide to export or import, it contains all the data on to which countries and to which companies they can sell the products they want to export by using the portal, The main functions of the portal can be summarized under the headings of the country overview, political environment, economic indicators, sectoral reports, import / export flows and foreign trade data.

Figure 2: Foreign Trade Portal Main Sections with TEB

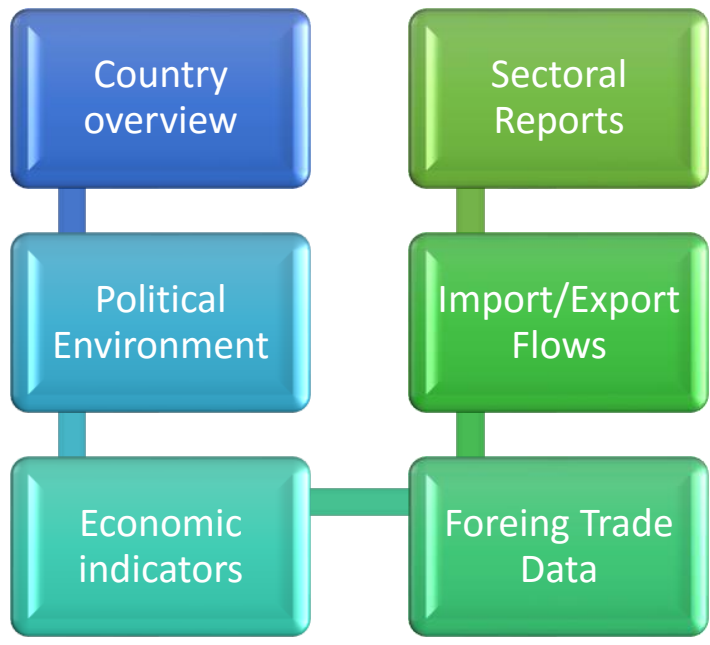

In order to analyze in detail the information and support provided to the companies that want to open foreign markets and / or foreign trade in the portal the results of one by one examination of the sections are given in the following sub-sections.

\subsubsection{Market Research Reports}

One of the most important issues for companies either will start foreign trade for the first time or that need to expand and diversify their existing foreign market is the methods and analyzes to be chosen in the determination of new market. Especially the companies that will open to the foreign market for the first time do not know the level of international competition of the product range they produce or sell locally, even if they estimate the level of competition abroad, they cannot control the dynamics of the market in which they can be competitive. The weakness in market control causes problems in terms of sustainability even if the opportunity to open to the foreign markets was seized.

Foreign trade portal offered to customers by Türk Ekonomi Bankası in case that importer or exporter Turkish companies wish to conduct market research regarding the country and / or industry they want to trade in, allows them to access market research reports prepared for the country or industry where information is requested from the database which is updated weekly by entering keywords in the 'Market researches' tab.

\subsubsection{Determination of the most appropriate country for the product to foreign trade}

Firms that obtain information about the market of the product produced, by examining the market research reports can identify the five most suitable countries for the sale of the product from the data warehouse prepared on the basis of Comtrade data by entering the HS code (Harmonized Product Definition and Coding System) of the product that they produce or plan to sell 
abroad by providing from the domestic market. If the HS code of the product is not known, the code can be provided by entering the name of the product in the search section. In the same way, by entering the HS code of my product, which is desired to be imported from abroad, the five most suitable importing countries can be displayed.

\subsubsection{Obtaining Information about the Identified Country}

In case the exporter or importer Turkish company needs to collect and compare information about the 5 countries listed as suitable for foreign trade, about these countries information below are provided:

In the overview section: Information on the population of the country, population growth rate, percentage of urban population, large city densities, face measurement, ethnic origin, official language, local time, exchange rate information, telephone code, internet extension, in which currency the invoice is made

In the Political Environment section: Information on the main political parties and their characteristics, including information on executive and legislative powers.

In the economic data section: gross domestic product (GDP), GDP per capita, share of Public Budget Balance in GDP, share of Public Debt in GDP, inflation rate, unemployment rate, current balance, data on the share of current balance in GDP in the last 5 years, sectoral distribution of the economic activities of the year and information on main industrial sectors.

\subsubsection{Customs Duty Calculation}

As a result of the comparative country analyzes performed for the group of goods subject to foreign trade, in order to calculate the customs duty applicable in the country it has decided, the local company enters into the relevant tab, the country of export, the country of import and manufacture, the mode of transport and the HS code.

\subsubsection{Identification of Required Shipping Documents}

After the country, product, taxes are cleared, the information on the country of export, the country of importation, the country of manufacture, the date of shipment, the mode of transport and whether the documents will be arranged by country or product and by selecting the HS code information in the relevant tab information about the required shipping documents can be obtained.

\subsubsection{Fair Chasing}

Fairs are the entities that allow buyers and sellers to come together to present and recognize products and services in detail. Fairs are also important in terms of being the platforms where technical development and changes are shared by bringing together many buyers and sellers in a certain period of time. TEB Foreign Trade portal allows foreign trade companies to obtain detailed information by using the country, city and sub-sector tabs of the related department in order to follow the fairs related to the sector in which they operate.

Fairs are a publicity event organized at regular intervals, usually at the same places, depending on a specific schedule for the promotion of goods or services, technological developments, information and innovations, the availability and purchase of market, technical cooperation, and the establishment and development of future commercial relations. At fairs buyers and sellers come together to realize various business agreements. At fairs, which are time-limited events, many exhibitors exhibit important products of one or more economic branches and exhibit sample products mainly to industrial wholesalers, industrial consumers and large purchasers (http://www.tobb.org.tr/fuar/2011).

\subsection{TEB - SME TV}

TEB - SME TV which is the first banking television channel established to support SMEs in the banking sector is broadcasting seven days and twenty-four hours in the categories of Entrepreneurship, Marketing and Sales, Tax and Law, Foreign Trade, Business life, Sectors, Management, Finance, SME Support and Production.

Under Foreign Trade Category it broadcasts under ten sub-categories as;

$$
\begin{array}{ll}
>\quad \text { Import-Export } \\
>\quad \text { Foreign Investment }
\end{array}
$$




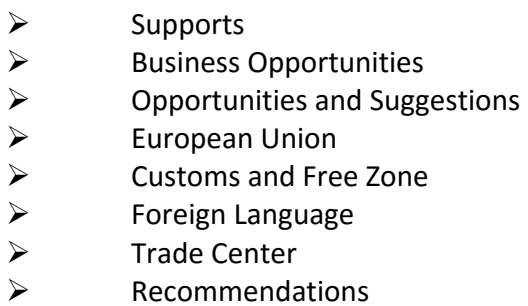

When the details of the broadcast were examined, it was observed that the experts had provided practical information on any subject that may be needed in addition to the legislation support to the newly started or the present foreign trade companies.

\section{CONCLUSION}

After economic liberalization, especially with Turkish Currency Protection Law No. 32 decision, the role of the banks in Turkey's economy opened outward has been moved to a more critical point. The banks along with acting as intermediaries for foreign trade transactions, they support firms engaged in foreign trade by providing cash loans, guaranteeing them through non-cash loans, offering derivative products and protecting them against currency risks. All said products are provided by all banks operating under deposit bank status. As for the Turkish Economy Bank, which was examined as a case study, is understood that it provides support for meeting all the criteria for being educated on foreign trade legislation, customs procedures which is considered as a critical success factor, mastering the dynamics of foreign markets to be traded and establishing strong business connections. The fact that the said bank contributes to foreign trade by means of different tools such as private television, incubation centers for SMEs, loan provision with special opportunities in cooperation with TIM, business development centers abroad, and web site that provides versatile macro and micro market analysis opportunities, separates it from a standard deposit bank.

It is understood that not-for-profit applications of the bank which are the subject of the case study, provided to support the foreign trade of the country, which require a significant knowledge and labor and technology infrastructure, go beyond the standard functions of the banking sector and contribute to the economy of the country. It is expected that this study to be considered as a guiding tool for students and academicians aiming to produce projects aimed at contributing to foreign trade and for firms dealing with foreign trade activities, especially SMEs in terms of meeting their consultancy needs.

In the empirical study, as a result of the cointegration analyzes conducted with the help of ARDL, FMOLS and DOLS methods, between the total volume of guarantee and volume of import and export made by the Eximbank loans used by banks in order to support the export and the volume of guarantees and letters of credit with the aim of supporting the imports. It was concluded that a $1 \%$ increase in the credit volume in the long term caused an increase in the foreign trade volume between $0.88 \%$ and $95 \%$. This result shows us once again how important it is for banks, one of the most important actors in the financial systems of the countries, to continue their activities effectively.

*All information used for TEB business case has been gathered through www.teb.com.tr and www.tebledisticaret.com.tr web sites which public has full access.

\section{REFERENCES}

20249 Sayılı Resmi Gazete. (1989, Ağustos 11).

Acar, O. (2009). Türkiye'de Dış Ticaret ve Dış Ticaretin Finansmanı. Ankara: Türkiye Ekonomi Politikaları Araştırma Vakfı.

Alpdündar, H. S. (2016). Türk Eximbank Kredilerinin Dış Ticaretteki Rolü. İstanbul: İstanbul Ticaret Üniversitesi Working Paper Series.

Altıntaş, H. (2006). Türkiye'de Para Talebinin İstikrarı ve Sınır Testi ve Sınır Testi Yaklaşımıyla Öngörülmesi. Erciyes Üniversitesi iisBF Dergisi (30), $15-46$. 
Çetin, A. K., Kutlutürk, M. M., \& Akmaz, H. K. (2014). Eğitimin Durumuna Göre İstihdamın GSYH Etkisi. Yönetim ve Ekonomi Araştırmaları Dergisi (22), 249-266.

Dhliwayo, S. (2017). Export experience and key success factors in cross-border trade: Evidence from Southern Africa. Acta Commercii Independent Research Journal in the Management Sciences , 1-19 17(1).

Doğan, M. (2013). Türkiye Sanayileşme Sürecine Genel Bir Bakış. Marmara Coğrafya Dergisi, 211-231.

Erdoğan, L., Ceylan, R., \& Tiryaki, A. (2018). Türkiye'de Uzun Dönem Ekonomik Büyümenin Belirleyicilerinin ARDL, FMOLS, DOLS, CCR Yöntemleriyle Tahmini. Hacettepe Üniversitesi Iktisadi ve Idari Bilimler Fakültesi Dergisi 36(4), 39-58.

Favero, C. A. (2001). Applied Macro Econometrics. Oxford: Oxford University Press.

Johnston, J., \& Dinardo, J. (1997). Econometric Methods. United States: McGraw Hill.

Karluk, R. (2013). Uluslararası ekonomi:teori politika. İstanbul: Beta Yayınları.

Kripfganz, S., \& Schneider, D. C. (2016). ardl: Stata module to estimate autoregressive distributed lag models. State Conference (s. 1-20). Chicago: State Conference.

Küçükaksoy, İ., Çiftçi, İ., \& Özbek, R. İ. (2015). İhracata Dayalı Büyüme Hipotezi. Çankırı Karatekin Üniversitesi 5(2), 691-720.

Kwiatkowski, D., Phillipps, P. C., \& Shin, Y. (1992). Testing the Null of Stationary Against the Alternative of A Unit Root: How sure are we that economic time series have a unit root? Journal of Econometrics, Vol. 29 159-178.

Madsen, T. K. (1989). Successful Export Marketing Management: Some Empirical Evidence. International Marketing Review, Vol 6, Issue 4.

Özdemir, Ü., Yiğit, G. K., \& Oral, M. (2016 (35)). Cumhuriyetten Günümüze Ekonomi Politikaları Bağlamında Türk Dış Ticaretinin Gelişimi. Eastern Geographical Review, 149-174.

Öztürk, S., Sözdemir, A., \& Koçbulut, Ö. (2007). Türk Eximbank Programlarının Türkiye İhracatına Etkileri ve AB/DTÖ'ye Uygunluğu. Süleyman Demirel Üniversitesi Iktisadi Idari Bilimler Fakültesi, 12 (2), 179-197.

Pallini, G. a. (2008). A Strategy to promote innovative small and medium enterprises. The World Bank, Poverty Reduction and Economic Management Department Latin America Finance and Private Sector Unit.

Pesaran, M. H., Shin, Y., \& Smith, R. J. (2001). Bound Testing Approaches to be Analysis of Long Run Relationship. Journal of Applied Econometrics 16(3), 289-326.

Yılmaz, E. G. (2018). IT Yatırımlarının Bankacılık Sektörü Üzerine Etkileri. Asos Journal, 25:39.

Yücel, A. (2019). İhracat Pazarlaması Stratejileri İle Firma Performansı İlişkisi. Fırat Üniversitesi Sosyal Bilimler Dergisi, $205-226$.

https://tebledisticaret.com

https://www.tbb.org.tr/tr/bankacilik/banka-ve-sektor-bilgileri/istatistiki-raporlar/59 (TBB; İstatistiki Raporlar, Türkiye'de Bankacılık Sistemi 1958 'den itibaren) 
ANNEX: 1

\section{TIM-TEB Cooperation Product and Service Fees Table}

\begin{tabular}{|l|c|}
\hline ww.tebledisticaret.com Platform ( for1 year ) & Free \\
\hline SWIFT MT103 Messages (Incoming / Outgoing) E-Mail Notification Service & Free \\
\hline Confirmed / Unconfirmed Export Letter of Credit Notification Service by E-Mail & Free \\
\hline Internet Banking Export File Observation Service & Free \\
\hline Document Delivery Tracking Service from Internet Banking & Free \\
\hline Global Account Management Service Fee & Free \\
\hline Check Collection (TEB Checks) & Free \\
\hline Check Collection (Other Bank Checks - TL) & $5 \mathrm{TL}$ \\
\hline Check Collection (Other Bank Checks - FC) & $50 \mathrm{TL}$ \\
\hline Foreign FC Collection Check Commission & $25 \mathrm{USD}$ \\
\hline Blocked Check Commission & $20 \mathrm{TL}$ \\
\hline Virtual Account Usage Fee (TL) & $50 \mathrm{TL}$ \\
\hline Virtual Account Usage Fee (FC) & $10 \mathrm{USD}$ \\
\hline Automatic Pool Account Usage Fee & $30 \mathrm{TL}$ \\
\hline
\end{tabular}

Source: Turkey Exporters Assembly 